\title{
Studies On Species Of Lactic Acid Bacteria Isolate Sr 12 From Bali Cattle Gastric With Conventional Method And Api Kit 50ch
}

\author{
Made Radwika $^{1 *}$, I Wayan Suardana ${ }^{2}$, I Dewa Made Sukrama ${ }^{3}$ \\ ${ }^{1}$ Student at Faculty of Veterinary Medicine; ${ }^{2}$ Laboratory of Veterinary Public Health, Faculty \\ of Veterinary Medicine; ${ }^{3}$ Laboratory of Clinical Microbiology, Faculty of Medicine, \\ University of Udayana, Bali \\ *Corresponding Author: radwikam@yahoo.com
}

\begin{abstract}
Lactic acid bacteria (LAB) are Gram positive bacteria that characterized by nonmotil, non-spore, negative catalase, coccus or bacillus cell shape, and live in microaerophilic condition with $\mathrm{CO}_{2}$ aeration 5-7\%. The purpose of study was to identifyy LAB isolate SR 12 isolated from gastrointestinal tract of bali cattle that previously known have potency as a source of probiotic. The study initiated by cultivation of isolate on de Man, Rogosa, Sharpe (MRS) medium, confirmation of isolate with Gram staining and catalase test as a main procedure for Gram positive indentification. The next identification in order to know the species of isolate was conducted both conventional test and kit API 50CH test. The result of study showed the LAB SR12 isolate as a genus of Pediococcusor Enterococcus according to its growth in temperature $10^{\circ} \mathrm{C}, \mathrm{pH} 9,6$ and it can't grow in halophilic condition. On the other hands, the use of ofAPI kit 50CH test showed the LAB SR12 was detected as Pediococcus pentosaceus.
\end{abstract}

Keyword: Bali cattle, Identification, Lactic Acid Bacteria, SR 12.

\section{INTRODUCTION}

Food processing through fermentation has been done by humans since prehistoric times. Pure culture of Lactic Acid Bacteria was found by $\mathrm{J}$. Lister in 1873 and use in cheese making as fermenter bacteria in 1890. Lactic Acid Bacteria (LAB) is a bacterium that can fermentate carbohydrate to lactic acid. Lactic Acid Bacteria can be divided into two groups, such as homofermentative LAB produce $95 \%$ lactic acid as a result of its fermentation and heterofermentative LAB produce not only lactic acid but ethanol and carbon dioxide as byproduct[1].It is known that cows gastrointestinal track are the habitat of several types of lactic acid bacteria which have good potential as probiotics[2-
5].Based on the results of previous research conducted by Suardanaet al in 2012 (unpublished data), it was found that from some strains of rumen origin of the Bali cattle, especially SR 12 is known to have the potential to be developed as a source of probiotics. This is based on the ability of isolate SR 12 to inhibit pathogenic bacteria with large inhibitory zones.

\section{RESEARCH METHOD}

Cultivation of LAB SR 12 isolate

The cultivation of BAL isolate SR 12 was done by isolate reculture that characterized by turbidity on MRS broth media. 


\section{Gram Staining}

Gram stain on SR 12 isolate was done by coloring preparations that have been fixed with crystal violet $2 \%$, lugol solution, acetone alcohol, and safranin. The staining results can be seen under a microscope with 1000x magnification.

\section{Catalase Test}

The catalase test was conducted to determine the activity of catalase enzyme. Positive results are characterized by bubbles.

\section{Conventional Test}

\section{Growth Test on $10^{\circ} \mathrm{C}$ Temperature}

A $10^{\circ} \mathrm{C}$ temperature test is conducted to determine the ability of bacteria to grow in low temperatures. Isolates that grow at this temperature are classified as Pediococcus, Lactobacillus, Enterococcus or Tetragonococcus. On the contrary, isolate that do not grow at this temperature are classified as Streptococcus.

\section{Growth Test on $\mathrm{NaCl} 15 \%$}

A $15 \% \mathrm{NaCl}$ test is conducted to determine the ability of bacteria to grow in hypersaline conditions. Isolates that grow at this condition are classified as Tetragonococcus. On the contrary, isolate that do not grow at this condition are classified as Pediococcus.

Growth Test on $\mathrm{pH}$ 9,6

A $\mathrm{pH} 9.6$ test was conducted to determine the ability of bacteria to grow in alkaline conditions. Isolates that grow at this $\mathrm{pH}$ are classified asEnterococcus. On the contrary, isolate that do not grow at this $\mathrm{pH}$ are classified as Lactococcus.

\section{API Kit 50CH Test}

The API test kit aims to identify species of lactic acid bacteria by utilizing the ability of LAB to ferment carbohydrates. The test was carried out with the Analytical Profiler Index kit.

\section{III.RESULT AND ANALYSIS}

Confirmation of Isolate BAL SR 12

\section{Gram Staining}

Gram staining results (Figure 1) show that LAB isolates SR 12 are Gram positive bacteria, and bacterial cells are coccus shaped. Based on its form, lactic acid bacteria SR 12 isolates belong to the genus Lactococcus, Aerococcus, Enterococcus, Streptococcus, Pediococcus, Leuconostoc [6].

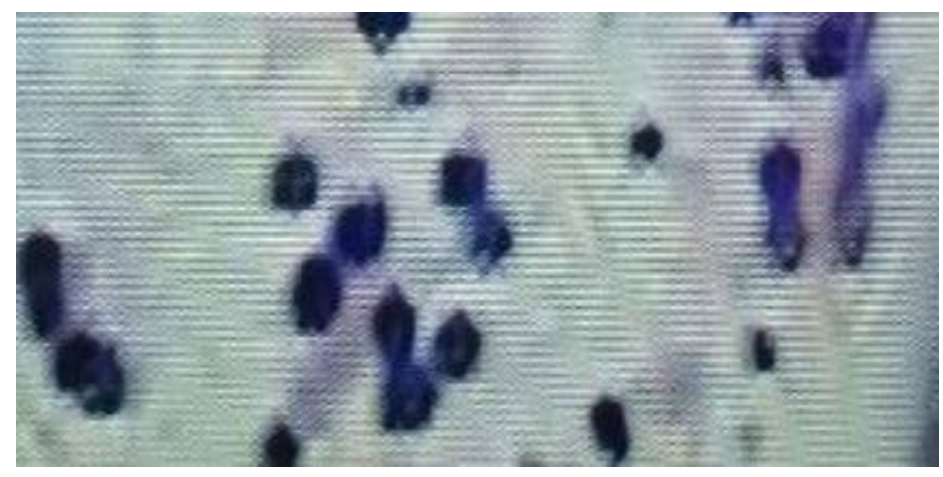

Figure 1. The results of Gram stain LAB isolate SR 12. The results of Gram staining bacteria showed that bacteria were Gram positive bacteria with a coccus shape 


\section{Catalase Test}

The principle of the catalase test is to detect active enzymes in bacteria that are useful in breaking down hydrogen peroxide (H2O2) into 2 molecules of water $(\mathrm{H} 2 \mathrm{O})$ and 1 molecule of oxygen $(\mathrm{O} 2)$. Catalase test results on LAB SR 12 isolates are presented in Figure 2.

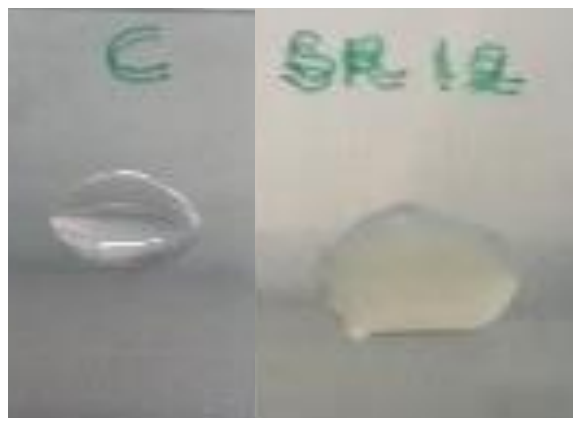

Figure 2. Result of catalase test on LAB SR 12 isolates. SR 12 isolates showed negative results.

Isolate Identification of LAB SR 12

\section{Conventional test}

Conventional tests are carried out with the aim of detecting BAL through its physiological characteristics. Conventional test results on LAB SR 12 isolates are presented in table 1.

TABLE 1. CONVENTIONAL TEST RESULT OF LAB ISOLATE SR 12

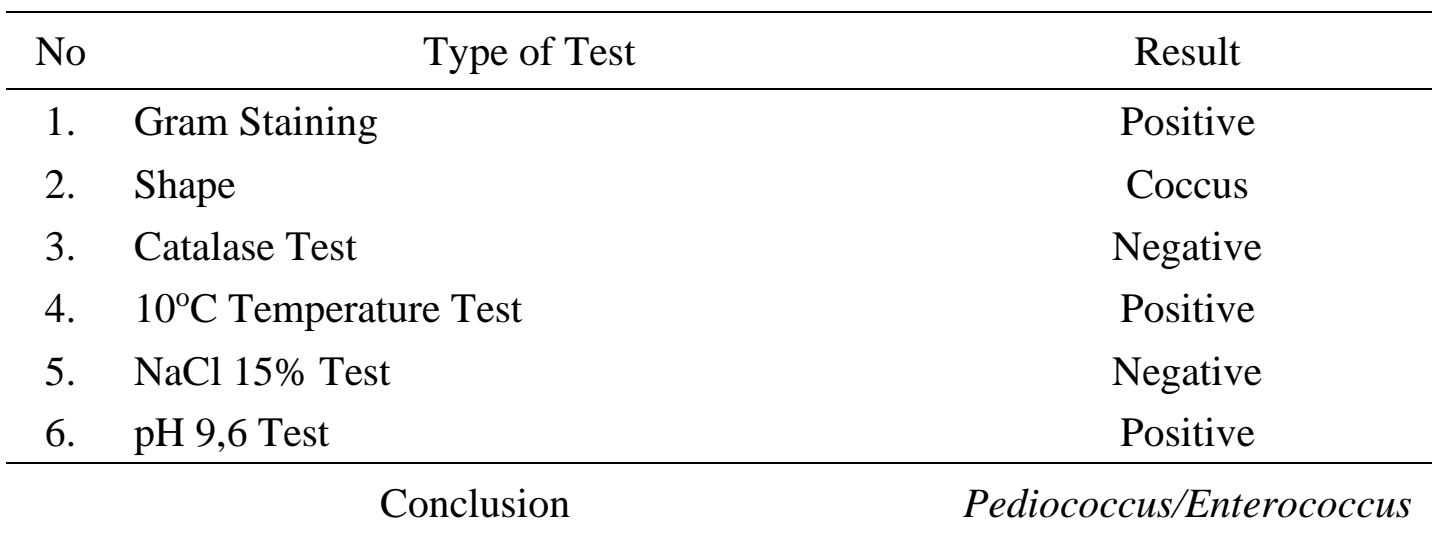

Based on the results of conventional tests, the LAB SR 12 isolates can be identified as the genus Pediococcus or Enterococcus based on the LAB classification through morphological and physiological characteristics [7].

\section{API Kit 50CH Test}

The API kit test was carried out to detect LAB isolates SR 12 by utilizing biochemical characteristics of isolate by testing 50 type of sugar. The API 50CH kit test results are presented in Figure 3. 


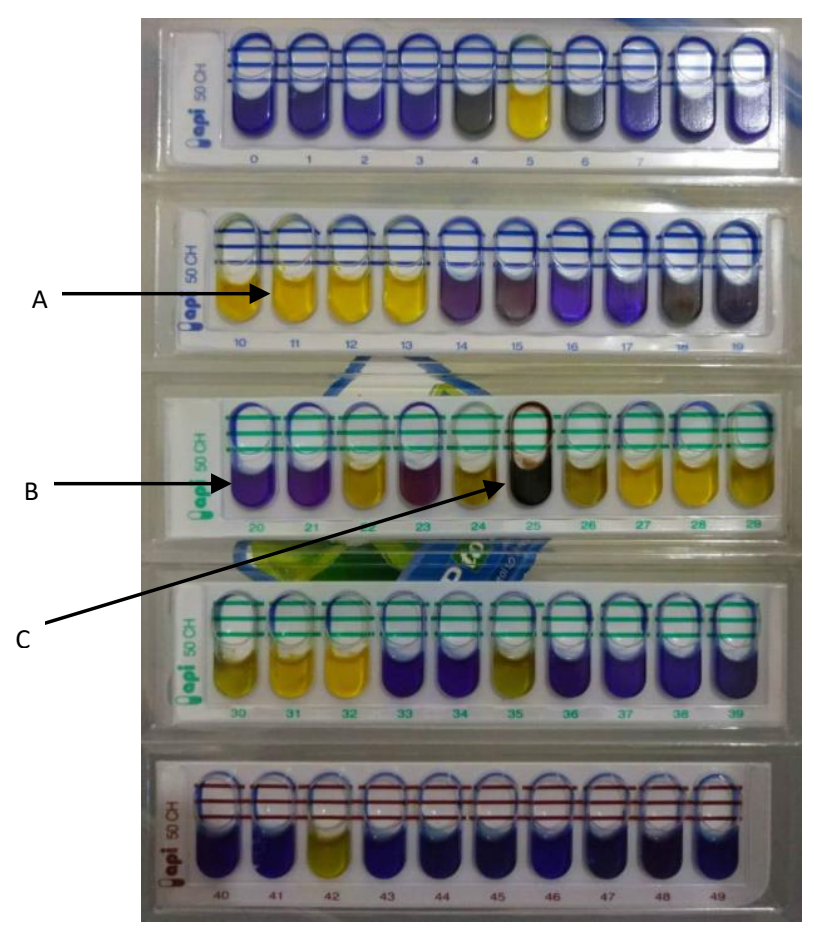

Figure 3. Results of API 50CH kit test on LAB SR 12isolates. (A). Positive results. (B). Negative results. (C). Positive control.

(A). Positive results (microtube no. 11) are marked by changes in color from blue to yellow; (B). Negative results (micotube no. 20) are marked with no discoloration; (C). On microtube no. 25 positive results were marked by reddish-black discoloration, this was due to hydrolysis of esculin ferric citrate to esculitin and glucose. Color changes caused by exculitin. The test results in Figure 3 are briefly as shown in Figure 4.

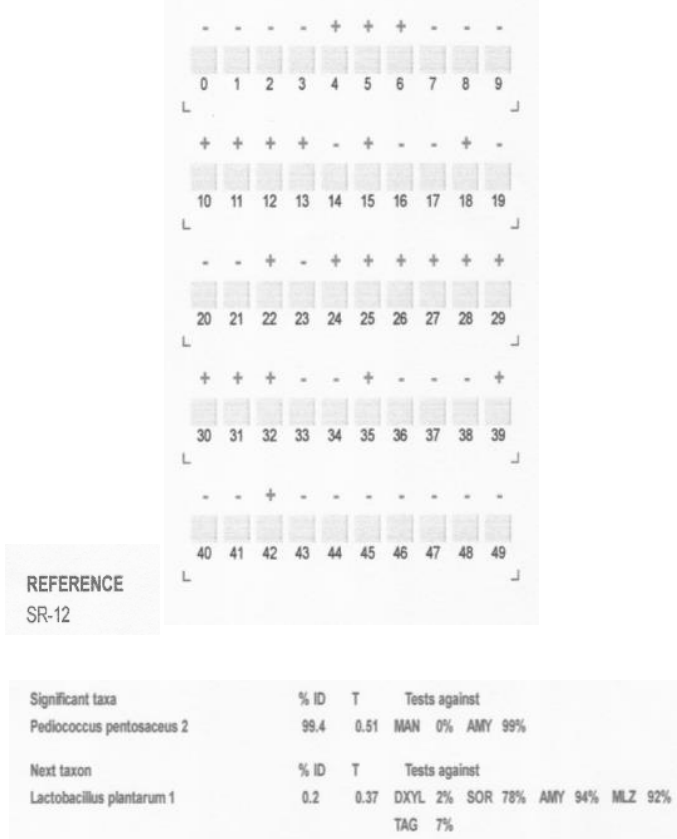

Figure 4. Test results of API Kit 50CH on apiweb 
Based on the results of the API $50 \mathrm{CH}$ kit test, LAB isolate SR 12 was identified as Pediococcus pentosaceus 2. The results of this study were the same as conventional tests. Pediococcus pentosaceus bacteria have various benefits, especially as probiotics. Borges et al in his study said Pediococcus pentosaceus in the form of frozen dry powder has the ability to inhibit pathogenic bacteria such as Listeria monocytogenes [8]. These bacteria can also be used as anti-obesity drugs by reducing the Body mass Index (BMI), waist circumference, and fat in the body [9]. Pediococcus pentosaceus bacteria is very useful in the process of fermentation of mackerel fish sausages by suppressing the growth of Enterobacteriaceae and Staphylococcus bacteria [10]. Sadeghi et al in his study found that Pediococcus pentosaceus has antifungal abilities [11]. Pediococcus pentosaceus bacteria also have benefits as a growth promoter in tilapia (Oreochromisniloticus) [12]. Pediococcus pentosaceus can also increase growth, quality of meat, and reduce the content of ammonia in the digestive tract of wild chickens [13].

\section{CONCLUSION}

The results showed that LAB SR 12isolates in conventional tests as Pediococcus / Enterococcus whereas in the API 50CH test kit showed Pediococcus pentosaceus 2.

\section{SUGGESTION}

Identification of LAB isolates SR 12 by utilizing physiological and biochemical characteristics still has some disadvantages, namely identification is limited to conventional tests and API $50 \mathrm{CH}$ kits. Therefore, it is necessary to carry out advanced conventional tests with more parameters.

\section{REFERENCE}

[1] Lásztity R. 2009. Food Quality And Standards - Volume III. EOLSS Publications, 2009.

[2] Widyadnyana DGA, Sukrama IDM, Suardana IW. 2015. Identifikasi Bakteri Asam Laktat Isolat 9A dari Kolon Sapi Bali sebagai Probiotik melalui Analisis Gen 16S rRNA. JSV 33(2): 228-233.

[3] Suardana IW, Cahyani AP, dan Pinatih KJP. 2016. Probiotic Potency and Molecular Identification of Lactic Acid Bacteria Isolated from Bali Cattle's Colon, Indonesia. Global Advance Research Journal of Medicine and Medical Science Vol. 5(5) pp. 143-149.

[4] Suardana IW, Suada IK, Sukada IM, Suarsana IN. 2009. Isolasi dan Identifikasi Isolat Bakteri Asam Laktat SR9 Asal Cairan Rumen Sapi Bali Sebagai Kandidat Unggul Probiotik. MEDICINA 2009; 40; 100-3.

[5] Suardana IW, Suarsana IN, Sujaya IN Wiryawan KG. 2007. Isolation and Identification of Lactic Acid Bacteria from Bali Cattle's Gastric Fluid as a Potential Candidate of Biopreservative. J.Vet. 8(4): 155-159

[6] Lahtinen S, Ouwehand AC, Salminen S, Wright A. 2012. Lactic Acid Bacteria. Microbiological and Functional Aspect Fourth Edition. CRC Press.

[7] Holzapfel WH dan Schillinger U. 1992. The genus Leuconostoc dalam: Widodo. 2003. Bioteknologi Industri Susu. Lacticia Press, Yogyakarta. pp: 33

[8] Borges S, Costa P, Silva J, Teixeira P. 2013. Effects of Processing and Storage on PediococcuspentosaceusSB83 in Vaginal Formulations: Lyophilized Powder and Tablets. BioMed 
Research InternationalVolume 2013, Article ID 680767, 8 pages.

[9] Higashikawa F, Noda M, Awaya T, Dashiitsoodol N, Matoba Y, Kumagai T, Sugiyama M. 2016. Antiobesity effect of Pediococcus pentosaceus LP28 on overweight subjects: a randomized, double-blind, placebo-controlled clinical trial. European Journal of Clinical Nutrition Vol. 70 pp: 582-587.

[10] Yin LJ, Jiang ST. 2001. Pediococcus pentosaceus $\mathrm{L}$ and $\mathrm{S}$ Utilization in Fermentation and Storage of Mackerel Sausage. Journal of Food Science Vol. 66(5): 742-746

[11] Sadeghi A, Raeisi M, Ebrahimi M, Sadeghi B. 2016. Antifungal Activity of Pediococcus pentosaceus Isolated from Whole Barley Sourdough. Journal of Food Quality and Hazards ControlVol. 3 pp:30-36.

[12] Cota-Gastélum LA, Luna-González A, González-Ocampo HA, FloresMiranda MC, Fierro-Coronado JA, Escamilla-Montes R, Peraza-Gómez V. 2013. Effect of Pediococcus sp., Pediococcus pentosaceus, inulin and fulvic acid, added to the diet, on growth of Oreochromisniloticus. African Journal of Microbiology Research, 7(48), 5489-5495.

[13] Chen F, Zhu L, Qiu H. 2017. Isolation and Probiotic Potential of Lactobacillus salivarius and Pediococcus pentosaceus in Specific Pathogen Free Chickens. Rev. Bras. Cienc. Avic. Vol. 19(2). 